\title{
Role of Translation in Geopolitical Agenda:Translator's Turns and Manipulation
}

\author{
Tatiana Vedernikova*, Natalia Shchurik, and Evgenia Kunitsyna \\ ${ }^{1}$ Irkutsk State University, 664003 Irkutsk, Russia
}

\begin{abstract}
The problem of translation used for geopolitical agenda, translation as a means of mind manipulation has long been of substantial interest to translation scholars. This article focuses on conscious and unconscious types of manipulation in translation and aims to show their manifestation in political discourse. On the one hand, nominalizations, euphemisms, politically correct vocabulary and metaphors make a translator or an interpreter choose between multiple interpretations. It brings him/her to unconscious choice. On the other hand, translators sometimes deliberately omit some parts of the text or change the order of the original. It means that a translator/interpreter consciously makes this or that decision concerning what part or parts of the source text are ideologically relevant and should be brought into "due" perspective in translation and which are to be left out, and is therefore instrumental in shaping public opinion.
\end{abstract}

\section{Introduction}

Translation is nearly always associated with manipulation in contemporary translation studies (G. Toury [1], I. Even-Zohar [2], T. Hermans [3], A. Lefevere [4], A. Dukate [5], I. Vehmas-Lehto [6], L. Venuti [7], A. Kramina [8]). Ideological programming of translation, translation and political engagement are of particular interest nowadays (M. Tymoczko [9], J. Munday [10], A. Sabermahani and M. Zandrahimi [11]). The topic of translation as manipulation is very wide vast and attitudes toward it are diverse. Crucial for our paper are the views that translation as a form of rewriting is manipulative in its nature (A. Lefevre) and the concept of "the translator's visibility" by L. Venuti. A. Kramina assumes that there are two types of manipulation in translation: conscious and unconscious [8]. This paper focuses on both types of manipulation in translation and aims to show their manifestation in political discourse. Relevant to the issue discussed are premises of the dialogical theory of translation by D. Robinson [12], his "translator's turn" as an idio/ideosomatic response in the dialogue with the author and source text. A graphic example of the translator's manipulative turn is synecdoche, i. e. a synecdochic translation, propagandistic by default.

\section{Methods and material}

For the purpose of the present research, an analytical method, observation and interpretation, definitional analysis, methods of critical discourse analysis and a comparative method are used. This approach helps to describe conscious and unconscious types of manipulation in translation.

The material for case study analysis is taken from current internet sources featuring political agenda.

\section{Results and discussion}

The problem of translation used for geopolitical agenda, translation as a means of mind manipulation has been for nearly a quarter of a century now of substantial interest to translation scholars.

According to A. Kramina, there are two types of manipulation in translation - conscious and unconscious [8].

There are two meanings of the term:

- [uncountable, countable] (disapproving) behavior that controls or influences somebody/something, often in a dishonest way so that they do not realize it. E.g., Advertising like this is a cynical manipulation of the elderly;

- [uncountable] (formal) the skillful control or use of something;

- data manipulation;

- manipulation of images [13].

The first meaning correlates with conscious manipulation and the second - with unconscious. As A. Kramina assumes, manipulation arising due to ideological, economic, and cultural considerations proceeds consciously, and thus might be termed conscious manipulation. Manipulation ascribed to the features of human psychology and manipulation due to ignorance (lack of language or world knowledge as well as psychological attitudes and judgements) might be termed unconscious manipulation [8].

Thus, a person's attitude to the problem determinates the choice of vocabulary and grammar patterns when describing it in a foreign language. But this might result in new meanings lacking in the source text or rather to a shift of meaning, as R. Jakobson puts it [14].

* Corresponding author: amistad@yandex.ru 
More often than not manipulation in the text can result in the usage of nominalizations, euphemisms, politically correct vocabulary and metaphors.

Contemporary English is characterized by extensive use of nouns and nominalizations instead of verbs. This tendency demonstrates a notable strive in the English speaking world for ambiguous nominations and unwillingness to choose a certain name for a certain thing. People try to avoid using verbs because these parts of speech mean responsibility.

Following L. Tenier, P. Seriot distinguishes between two types of nominalizations: static and dynamic. We assume that static nominalizations can be correlated with frames and dynamic - with scenarios [15]. Nominalization is a hidden meaning corresponding to scenario presented in deep structures. These are nominalizations-scenarios that contain various implicatures and the author's intentions in deep structures.

In the framework of this study, in spite of diversity in distinguishing these phenomena, the Taylor's classification is in focus [16]. According to it frames are stable and scenarios are more flexible and dynamic coherent cognitive structures.

Translating such kind of structures can be a real challenge for a translator.

Let us take a phrase "What is the ask?" [17]. Ask is predominantly used as a verb but here we see a noun. Moreover, it is impossible to translate this phrase without the context.

An alternative and more conventional way to express this meaning would be "What are they asking?" - "Что они требуют?" It should be noted, however, that when we use "What is the ask?", we emphasize rather the action itself (implying that a certain assignment, request or demand should be fulfilled) not the person fulfilling the task. Nominalizations make actions impersonal, which means that the occurrence of an action is important for recipient, not the person involved in it. In translation the verb "требовать" will cause a loss of the author's dual intention.

"What are we being asked to do?" is another way to interpret this phrase. It can be translated as "Что от нас требуют, чтобы мы сделали?"

Such a choice helps to convey both the message and the purpose of the phrase: there is a demand which should be fulfilled.

Such a wording implies that we are faced with a demand from someone who is perhaps of a senior position and the message is obvious - we must follow the instructions; the inequality between a person and society or between different nations is felt.

This way of translation "disrupts" the original since he/she has to choose only one alternative. Multiple interpretant is lost. The best way is to use a noun instead which can retain the nominalization based on the author's multiple intention and manipulative potential of the phrase.

The verb "to ask" can be translated into Russian as “требовать" or "просить". Accordingly, the translation would be "Какое требование?”, "В чем суть просьбы?”
Another translation of Putin's speech demonstrates the tendency of using nominalizations and as a consequence leads to manipulation.

“И под эту задачу “скроили” и бюрократический аппарат ОБСЕ, который абсолютно никак не связан с государствами-учредителями".

"And this task is also being accomplished by the OSCE's bureaucratic apparatus which is absolutely not connected with the state founders in any way" [18].

The expression "Is being accomplished" can be understood as "to bring about (a result) by effort, to bring to completion to succeed in reaching (a stage in a progression)" [19]. The grammatical form shows that the process has not been completed yet. The general idea is transmitted quite adequately but the proposition and implicature are transformed. Such technique of translation provides multiple interpretation

In 2015 a Russian translators' journal Mosty featured an article "Na ideologicheskom fronte bez peremen" ("All Quiet on the Ideological Front"). Its authors D. Ermolovich and P. Palazhchenko explore a famous UN resolution which was issued after downing of Boeing 777 Malaysia Airlines, from Amsterdam to Kuala Lumpur, on 17 July 2014 while flying over eastern Ukraine [20]. Unfortunately, the authors overlooked the difference between shooting down and downing of the aircraft. They express a strong doubt that it was a victory of Russian diplomats thanks to whom a more general phrase downing of the aircraft rather than shooting down was used in the resolution.

The Security Council, "Deploring the downing of a civilian aircraft on an international flight, Malaysia Airlines flight MH17, on 17 July in Donetsk Oblast, Ukraine, with the loss of all 298 passengers and crew on board" [21].

The phrase shooting down had been used in many resolutions before. "Shooting down of two civil aircraft on 24 February 1996" [22] or "Ultimately, the members of the Security Council expressed regret for the loss of life and stressed the need to resolve the Iran-Iraq War. ... The Council "deeply deplored the tragic incident", but did not condemn the U.S. since the shoot-down was the result of errors" [23].

As a matter of fact this is a precedent phenomenon implying violence and aggression. And on the contrary downing of the aircraft is neither a term nor a set expression. It is a conventional nominalization which is based on multiple interpretant. Nevertheless based on the context this phrase can be understood differently. It is a victory of Russian diplomacy without a doubt.

Conscious manipulation in translation presupposes the use of certain techniques to impact the addressee. In this case it is viewed within the framework of dominating ideology.

An ideology may be defined as an organization of ideas that work to unconsciously shape and constrain an individual's beliefs and actions. It involves making certain beliefs and concepts seem natural, and simply 'the way things are' [24].

Taking this view as our basic starting point we are going to analyze a script from "Putin" which aired on September 27, 2015 (Charlie Rose, the correspondent, 
Andy Court, the producer). The Russian version is available at http://www.kremlin.ru. The English version is available at https://www.cbsnews.com.

For the purposes of our investigation, let us specify that the material presented is named $a$ script - that is the written version of a programme.

John Adams, one of the American Founding Fathers and second president of the US, wrote that the new settlements in America were "the opening of a grand scene and design in Providence for the illumination of the ignorant, and the emancipation of the slavish part of mankind all over the earth" [25].

This stance became the cornerstone of American ideology - the US has the moral right to dictate to the rest of the nations which path to follow and which way to live.

One of the key techniques to render ideological impact is to exclude the whole text or its parts from translation. This technique is widely explored in P. Johnson's paper on Pablo Neruda's Canto General during the McCarthy Years in the U.S. [26]. Special attention is given by N. Rudnitskaya to subjects and ways of ideological influence over translation; textual traits, causing ideological ban or censorship [27].

In the American version of the interview one can see how the main concepts of American ideology are manifested in omission of the whole remarks or their parts. This is, in terms of D. Robinson's dialogic theory of translation, a synecdochic translation, that «wants to treat the part as the whole» [12]. If some parts of a text literally contradict the translator's (or, in the given case, those he represents') views, the translator «treats the parts that he or she does not like (feels uncomfortable with) as excess, superfluous, as dross that can be sloughed off in the TL, and translates only the parts he or she likes (abridgement), or translates the whole thing in terms of the parts he or she likes (assimilation). <..> The synecdochic translator $\langle\ldots\rangle$ sets up a different sort of dialogue with the SL writer: an equally friendly one, perhaps, but the friendliness tends more toward condescension than subservient admiration» [Ibid.]. D. Robinson associates synecdochic translation with propaganda (cf. propagandistic translation), which he understands as any bringing of «the truly important parts of» the SL text (whatever genre it may belong to, including belles-lettres) «into proper perspective» (see [Ibid.]). Our focus here is on political propaganda as an instance of mind manipulation and thus on "proper (desired) perspectivization" of the original message in translation. One can hardly suspect the ideologicallyminded (or, rather, biased) translator of «subservient admiration» for the SL text, let alone the opponent himself; as far as condescension is concerned, its propositional content may be exemplified by such translatorial assumptions as I know better what is to be emphasized / clarified, or I know (I am to judge and to decide) what would be in line with the readers' expectations and what had better be left out, etc. A synecdochic translation as a manifestation of the translator's ideosomatics arising from collective ideology (D. Robinson's term as opposed to that of idiosomatics that derives from individual experience [Ibid.]) is eo ipso an instance of conscious, well-targeted manipulation of public opinion.

Before turning to the interview of the Russian President and its English version, we shall allow ourselves to refer to a couple of facts. The U.S. is a superpower. And «the policymakers of the early twentieth century did not mince their words: "God has not been preparing the English speaking and Teutonic peoples for a thousand years for nothing but vain and idle self-admiration. No! He has made us the master organizers of the world to establish system where chaos reigns. ... He has made us adepts in government that we may administer government among savages and senile peoples." This revealing gem was uttered by Senator Albert T. Beveridge when the United States originally sought to annex the Philippines» [28]. Hillary Clinton, the Democratic Party's nominee for president 2016, made a case for American exceptionalism and leadership around the world, saying that other countries would step in to fill the vacuum and calling America "the global force for freedom, justice and human dignity" [29]. https://www.rt.com/usa/357801-clintonamerican-exceptionalism-speech/ Mrs. Clinton followed Barak Obama, the first President since 1981 to use the then taboo term "American Exceptionalism" in public [30].

Let us see now how the above mentioned technique of deliberate omission (sloughing off) is implemented in the American version of the interview with V. Putin.

The Russian version of the interview starts with a question to V. Putin about his forthcoming address to the United Nations. Then the interlocutors move to the topic of war in Syria.

In American variant the interview starts with the question about Russian involvement in the Syrian operation led by the US. The fragment concerning address to the U.S. is left out.

Charlie Rose: So you would like to join the United States in the fight against ISIS? < ..>

Thus, the idea of dominating role of the US in the world is expressed.

"America was established not to create wealth but to realize a vision, to realize an ideal - to discover and maintain liberty among men."- W. Wilson, the 28th President of the United States of America. <...>

This idea is foregrounded in the American version of the interview by omitting from it the criticism of the US operations in Syria, Iraq and Libya. V. Putin blames the US for overthrow of the legitimate power in Libya which led to civil disorders.

В. Путин: А как Вы считаете, правильно ли поступают те, кто поддерживает вооружённую оппозицию и, главные образом, террористические организации только для того, чтобы свергнуть Асада, не заботясь о том, что будет со страной после полного уничтожения государственных институтов в этой стране? Мы уже проходили это, я уже упоминал Ливию. Только что, совсем недавно это было. Соединённые Штаты активно помогали разрушать эти государственные институты. Хорошие они были или плохие - это другое дело. Но они разрушены, после этого Соединённые Штаты понесли тяжёлые 
утраты, в том числе и гибель своего посла. Понимаете, к чему это приводит?

Поэтому мы помогаем именно государственным легальным структурам, но, я хочу подчеркнуть это ещё раз, в надежде на то, что в Сирии будут проводиться необходимые для сирийского народа политические преобразования.

Вы всё время, неоднократно, с настойчивостью, которая достойна лучшего применения, говорите о том, что сирийская армия борется со своим народом. Но Вы посмотрите, кто контролирует 60 процентов территории Сирии. Где эта цивилизованная оппозиция? 60 процентов территории Сирии контролирует либо ИГИЛ, либо другие - «Джебхат ан-Нусра» и прочие террористические организации, организации, которые признаны таковыми, в качестве террористических, и Соединёнными Штатами, и другими государствами, и ООН. Они [эти террористические организации], а не кто либо другой, контролируют почти 60 процентов сирийской территории.

President Putin: Well, tell me, what do you think about those who support the opposition and mainly the terrorist organizations only in order to oust Assad without thinking about what will happen to the country after all the government institutions have been demolished? Today, you have repeatedly said that Assad is fighting against his own population. But look at those who are in control of 60 percent of the territory in Syria. It's controlled by either ISIS or by others $\langle\ldots$. >

Charlie Rose: Al-Nusra?

President Putin: such as al-Nusra and other terrorist organizations. They are recognized as terrorist organizations by the United States, by other states and by the United Nations.

The next example contains the implied accusation of the US of the dire situation in Afghanistan, Iraq and Libya. It was not included into the American version.

В. Путин: А Россия никогда не принимала, не принимает и не собирается принимать участия в действиях, направленных на свержение легитимной власти. Я сейчас говорю о другом - о том, что если кто-то делает это, то результат очень тяжёлый. В Ливии - это полная дезинтеграция государства, в Ираке - это заполнение этой территории террористами, в Сирии к этому же, похоже, идёт, в Афганистане ситуация вы знаете какая.

President Putin: Russia has not taken part and is not going to take part in any actions aimed at removing the legitimate government. $<\ldots>$

The American media the Syrian leader Bashar-alAsad is portrayed as a man who is exercising tyranny in Syria. ISIS on the contrary is often presented as democratic rebels. The information contradicting this view is deleted from the American version.

В. Путин: Выражаясь профессиональным языком спецслужб, могу сказать, что такая оценка - это явное активное мероприятие врагов Асада. Это антисирийская пропаганда, ничего общего между Асадом и ИГИЛ не существует, они воюют друг с другом. И повторяю ещё раз: Асад и его армия единственная сила, которая реально воюет с ИГИЛ.
President Putin: Well, speaking in a professional language of intelligence services I can tell you that this kind of assessment is an "active measure" by enemies of Assad. It is anti-Syrian propaganda <...>

V. Putin's words about the Russian national pride and greatness are also omitted from the American version of the interview. It as well lacks the description of Russian operations to protect its interests.

В. Путин: Это не является нашей самоцелью. Я горжусь Россией и уверен: подавляющее большинство граждан моей страны испытывает чувство любви и уважения к своей Родине. Нам есть чем гордиться: и российский культурой, и российской историей. У нас есть все основания верить в будущее нашей страны. Но у нас нет какого-то фетиша по поводу супердержавности России на мировой арене. Мы занимаемся только одним - защитой своих коренных интересов.

President Putin: Well, it's not the goal in itself. I'm proud of Russia, that's true. And we have something to be proud of, but we do not have any obsession with being a superpower in the international arena.

\section{Conclusion}

Translation is manipulative in nature. When it comes to terms of political discourse, political interlingual interaction, translation appears ideologically charged and is instrumental in shaping public opinion. There are two types of manipulation in translation - conscious and unconscious:

1) one of the key techniques to render ideological impact is to exclude certain parts from translation; the result is a synecdochic translation, abridging the text in such a way and with a view to bring «into proper perspective» only those parts of the SL text that are found important and / or not jeopardizing the status quo or authority or mainstream ideology.

2) translation of nominalizations, euphemisms, politically correct vocabulary and metaphors make a translator or interpreter choose between multiple interpretations. Nominalizations usually have dual meaning. Not always but very often they are stylistically marked. If a translator/interpreter has negative attitude to the problem, a person or situation in most cases he/she chooses a marked variant of translation instead of a neutral one.

\section{References}

1. G. Toury, Descriptive Translation Studies and Beyond (John Benjamins Publishing Company, 1995)

2. I. Even-Zohar, International Journal for Theory and Analysis of Literature and Communication 11(1), (1990)

3. T. Hermans, Translation in Systems. Descriptive and System-oriented Approaches (Routledge, 2014)

4. A. Lefevere, Translation, Rewriting and the Manipulation of Literary Fame (Routledge, 1992) 
5. A. Dukate, Manipulation as a Specific Phenomenon in Translation and Interpreting. URL: http://www3.acadlib.lv/greydoc/Dukates_disertacija/ Dukate_ang.doc (date of access February 01.2017).

6. I. Vehmas-Lehto, Translation Studies: In search for vigour and relevance. URL : https://helda.helsinki.fi//bitstream/handle/10138/337 85/Translation_Studies_AFinLa.pdf?sequence $=2$ (date of access 1 May 2018).

7. L. Venuti, The Translator's Invisibility: A History of Translation (Routledge, 2008)

8. A. Kramina, Studies about Languages 6, 37-40 (2004)

9. M. Tymoczko, The Translator 6(1), 23-47 (2000)

10. J. Munday, The Translatorn13(2), 195-217 (2007)

11. A. Sabermahani, M. Zandrahimi, Translation Studies Quarterly, 14(53).

URL: http://journal.translationstudies.ir/ts/ article/view/324

12. D. Robinson, The Translator's Turn (Baltimore and London: The Johns Hopkins University Press, 1991)

13. Oxford Dictionaries (Oxford University Press). URL: https://www.oxfordlearnersdictionaries.com/definiti on/english/manipulation (date of access 19 February 2017)

14. R.O. Jakobson, On Linguistic Aspects of Translation. Selected Writings II: Word and Language, 260-6 (The Hague and Paris: Mouton, 1959/1971)

15. P. Seriot, Russian language and Soviet political discourse: analysis of nominalization (The area of meaning: The French school of discourse analysis, 2002)

16. J.R. Taylor, Linguistic Categorization. Prototypes in Linguistic Theory (Oxford: Clarendon Press, 1995)

17. New York Times. URL: http://opinionator.blogs.nytimes.com/2013/04/05/the -dark-side-of-verbs-as-nouns (date of access 11 June 2016)

18. Apiural. URL: http://www.apiural.runews/politics/60915/ (date of access 2 December 2016)

19. Dictionary by Merriam-Webster: America's mosttrusted online dictionary. URL: https://www.merriam-webster.com (date of access 14 May 2018)

20. D.I. Ermolovich, P.R. Palazhchenko, Journal of Translators 1(45), 21-29 (2015)

21. United Nations. URL: http://www.un.org/press/en/2014/sc11483.doc.htm (date of access 19 February 2017)

22. United Nations. URL: https://www.un.org/press/en/2015/sc11775.doc.htm (date of access 19 February 2017)

23. United Nations Security Council Resolutions. URL: http://unscr.com/en/resolutions/doc/1067 (date of access 19 February 2017)
24. B.L. Ott, R.L. Mack, Critical Media Studies. An Introduction (Wiley-Blackwell Publishing, 2010)

25. J. Adams, The Works of John Adams, the Second President of the United States. URL: https://books.google.ru/books (date of access 19 February 2017)

26. P. Johnson, Journal of Siberian Federal University. Humanities \& Social Sciences 2, 229-243 (2015)

27. N.N. Rudnitskaya, Baltijskij gumanitarnyj zhurnal 1 (2013)

28. S. T. Asma, The Humanist (1993)

29. Full Speech: Hillary Clinton Speech at The American Legion convention in Cincinnati. URL: https://www.rt.com/usa/357801-clinton-americanexceptionalism-speech/ (date of access 11 February 2017). Z. Stepp, President Obama's Reclaiming of American Exceptionalism. URL: https://www. huffingtonpost.com (date of access 21 March 2018) 